\title{
Alfred Werner's Role in the mid-20th Century Flourishing of American Inorganic Chemistry
}

\author{
Jay A. Labinger
}

\begin{abstract}
The development of organic and physical chemistry as specialist fields, during the middle and end of the 19th century respectively, left inorganic behind as a decidedly less highly regarded subfield of chemistry. Despite Alfred Werner's groundbreaking studies of coordination chemistry in the early 20th century, that inferior status remained in place - particularly in the US - until the 1950s, when the beginnings of a resurgence that eventually restored its parity with the other subfields can be clearly observed. This paper explores the extent to which Werner's heritage - both direct, in the form of academic descendants, and indirect - contributed to those advances.
\end{abstract}

Keywords: History of inorganic chemistry · Werner, Alfred

\section{Historical Background}

Modern chemistry is usually considered to begin with Lavoisier, in the late 18th century, but its separation into distinct sub-specialties was not generally recognized until well into the 19th century. The earliest references to the terms 'organic chemistry' and 'inorganic chemistry' in the Oxford English Dictionary both date from around the same time - the late $1820 \mathrm{~s}$ and 1837 respectively - but their statures quickly diverged. Most of the important developments over the next half-century came from the organic realm, as we can see from a few (entirely typical) quotes from historians of chemistry:

"Between 1870 and 1890 the rapid development of organic chemistry gave it such a relative prominence that the other branches of the science rather suffered in consequence. Inorganic chemistry particularly seemed to be drifting towards the discouraging position of a completed sci- ence, and some predicted for it little further growth."[1]

"Organic chemistry was riding high.... Inorganic chemistry, which under Berzelius had been the dominant branch, was beginning to look like a poor relation."[2]

"If we glance back over the labors of the last fifty or sixty years, we recognize that organic chemistry has gone on preponderating more and more over inorganic.” [3]

Towards the end of the 19th century, physical chemistry emerged as a competitor for organic's prestige, with inorganic relegated to a poor third-place showing. A quantitative assessment of the respective levels of interest in the three subfields can be inferred from the frequency of appearance of the corresponding terms in books in English, shown in Fig. 1. Consistent with the OED entries, organic and inorganic first appeared in the 1820s and 1830s respectively, with the former outstripping the latter by at least five-fold from the beginning. Physical showed up in the 1880s and almost immediately surpassed inorganic, which remained in its state of relative neglect well into the 20th century - indeed, by this measure (but not by others, as we shall see shortly), even up to the present.

I have documented elsewhere ${ }^{[4]}$ a dramatic rise in the stature of inorganic chemistry, particularly in the USA, beginning around the middle of the 20th century. Perhaps the first to explicitly recognize that development - in medias res, as it were - was Ronald Nyholm, in 1956:

"Those of us who were familiar with the state of inorganic chemistry in universities twenty to thirty years ago will recall that at that time it was widely regarded as a dull and uninteresting part of the undergraduate course....The factors primarily responsible for the modern forward-looking spirit in inorganic chemistry are two external developments, which give it, first, a new sense of purpose, and, second, new tools with which to achieve this purpose.."[5]

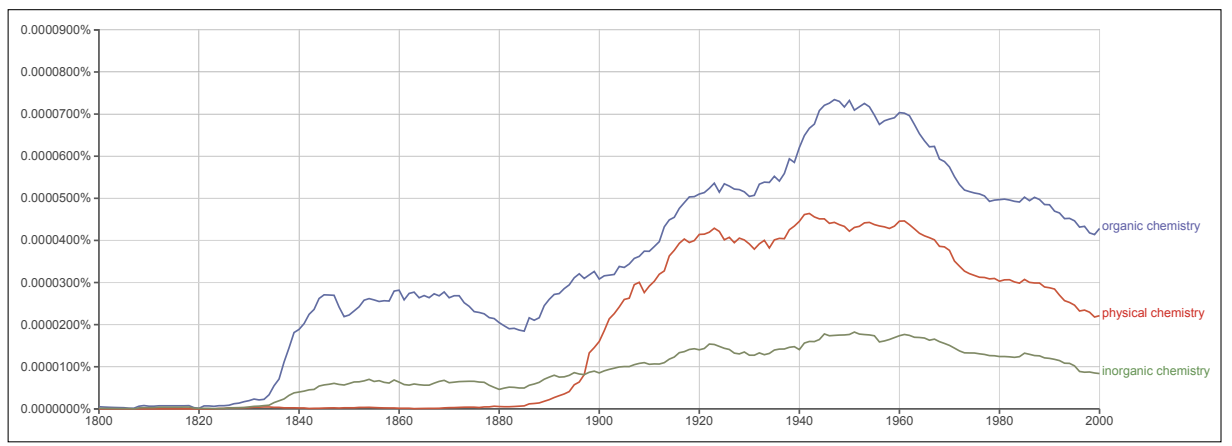

Fig. 1. Frequency of appearance of the phrases 'organic chemistry' (blue trace), 'physical chemistry' (red trace) and 'inorganic chemistry' (green trace) in books in English, 1800-2000. Generated using Google Books Ngram Viewer, http://books.google.com/ngrams. 
While I don't agree with his assessment of the main causes - in my view the central developments were internal, not external, to the field - unquestionably his perception that a sea-change was underway was accurate and prescient. Fig. 2 summarizes some quantitative support for that claim (see ref. [4] for a more complete presentation of these data, as well as an explanation of the methodology used to collect them): activity in inorganic chemistry, as measured by publications and presentations, shows a sharp upturn relative to that in organic and physical chemistry beginning in the 1950s. The corresponding heightened recognition of the subfield, in terms of awards and honors, follows some 20 years later. By the end of the 20th century inorganic has reached full parity with its previously more prestigious relations according to all of these metrics, even surpassing them in some aspects.

Why did it take so long for inorganic chemistry to become respectable? My contention $^{[4]}$ is that, up until the mid-20th century, it was viewed - not inaccurately as a mostly descriptive, phenomenological discipline, lacking the systematizing and explanatory power that characterized first organic and then physical chemistry. As one historian sums up:

"Organic chemistry developed a program of study, a language of discourse, and a system of explanation that was foreign to the practitioners of an earlier general chemistry."'6]

Indeed, for much of this period of history inorganic chemistry was scarcely if at all distinguished, in most practitioners' minds, from a more nondescript 'general chemistry.' One exception does stand out, however: Alfred Werner's groundbreaking studies in coordination chemistry during the late 19th and early 20th century. That work was brilliantly systematic and explanatory, and certainly could, one might have thought, have served to nucleate the growth of inorganic chemistry - but it did not, at least not for several decades:

"It was simply not true that coordination complexes played a key role in inorganic chemistry either then [just before the First World War] or for 40 years ahead. What Werner did do in his own fairly short lifetime was to convince people that in this area... his theory was a satisfactory explanation."'[7] (emphasis in the original)

The body of this paper will examine that delay - why a Wernerian school of inorganic chemistry did not develop promptly - and try to trace Werner's influence on the eventual renaissance of inorganic chemistry in the USA.
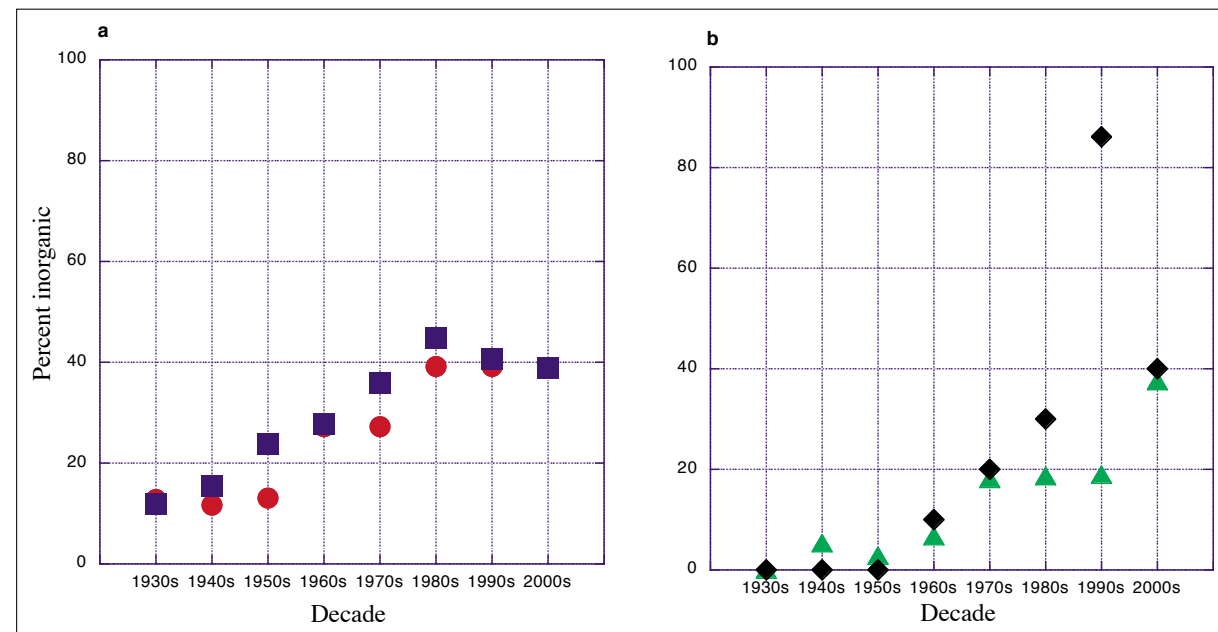

Fig. 2. Representation (as a percentage) of inorganic chemistry relative to the total of organic + physical + inorganic. a: Publications in Journal of the American Chemical Society (red circles); presentations at American Chemical Society national meetings (blue squares). b: Members elected to the National Academy of Sciences (green triangles); winners of the ACS Award in Pure Chemistry (black diamonds).

\section{Werner's (lack of) Successors}

Alfred Werner's career has been studied extensively, most notably by George Kauffman, ${ }^{[8]}$ and only the briefest of recaps is appropriate here. He began as an organic chemist, completing his $\mathrm{PhD}$ dissertation in 1890 in Zürich, at what was then known as the Polytechnikum (now the ETH) with Arthur Hantzsch, on the stereochemistry of organic nitrogen compounds. While working on his Habilitationsschrift (in the same area, at the same institution), he turned his attention to the nature of coordination compounds such as the metal-ammines of which understanding was completely lacking at the time - probably (according to Kauffman) initially stimulated by needing to prepare a lecture on the topic in 1892 . Before the end of that year he came up with his theoretical framework - published the next year ${ }^{[9]}$ - that successfully explained essentially all known and forthcoming observations, and has endured, little changed, to this day. Largely on the strength of that triumph, he was called to the University of Zürich, where he remained until his death in 1919.

During his $25+$ years on the faculty, Werner supervised around $200 \mathrm{PhD}$ students and a number of (what we would now call) postdocs and visiting associates; some of these worked on organic topics, to be sure, but the majority of his effort, especially from 1900 on, was focused on coordination chemistry. ${ }^{[8]}$ Many commentators have been struck by the fact that, despite such an abundance of Werner-trained PhD chemists, virtually none chose to carry on with his research program, either before or after his death:

“Although Werner had an enormous influence on the development of coordination chemistry, it is probably not correct to talk about a Werner School of inorganic chemistry in Zürich or elsewhere....it is quite surprising how few of Werner's numerous doctoral students went on to academic careers. In part, the reason for this lies in the dominance of overseas students in his research group. A majority of them returned to their homelands after completing their studies in Zürich, but did not establish local schools of coordination chemistry." [10]

The 'dominance of overseas students,' including as we shall see a handful from the US, might account for the absence of a Werner school in Switzerland, but none was established elsewhere either, including the UK:

"The subject was essentially ignored by the great body of chemists who associated it with the metal ammines whose chemistry they regarded as dull and useless. That view took a long time to die. It was still very much alive when I was a student in Cambridge during the period 1935-1940.” [11]

Why? Kauffman offers two interpretations - not identical, but both carrying a flavor of (unintentional) intimidation:

“Werner's work was so complete and all-encompassing that for many years coordination chemistry was neglected because most chemists thought that all the important research had been done." ${ }^{[12]}$

"Perhaps the impact of Werner's powerful, authoritarian personality and the impression of his control and mastery of 
his field deterred most of those who had worked with him from any thought of following in his footsteps." $[8]$

Whatever the reason(s), with the exception of Paul Pfeiffer, none of Werner's European students or associates went on to any significant accomplishments in inorganic chemistry. What about in the US?

\section{Werner's American Colleagues}

Kauffman lists five Americans who did their doctoral work with Werner - Emil Grebe (1898), Walter Peters (1901), Jenny Kruh (1911), Victor L. King (1912), and Helen Somersby French (1913). ${ }^{[13]}$ I have not been able to learn much about the first three, in part because of the rather haphazard practices of authorial designation at the time, making it difficult to track people by publication record. Werner generally credited students only as responsible for the experimental part, citing himself as sole author, as in the example reproduced in Fig. $3,{ }^{[14]}$ the only reference to Grebe I have found.

No paper appears to mention Kruh, but she did have a book published (by the University of California, in 1911) with the title 'Über die inneren Metallkomplexsalze,' presumably the contents of her PhD thesis. Kauffman's complete Werner bibliography ${ }^{[8]}$ includes one paper 'with' W. Peters; unlike Grebe and Kruh, he apparently worked on a purely organic project. ${ }^{[15]}$ I have found no evidence of post-PhD careers in chemistry for any of these three students. There was a Walter Peters (1876-?) who achieved some fame as a chemist, even to the extent of having a reaction named for him - formation of organomercurials from $\mathrm{HgCl}_{2}$ and sulfinic acids - but he can't be the one Kauffman cites: this Peters received his $\mathrm{PhD}$ in Strasbourg in 1903, and apparently never worked with Werner at all. ${ }^{[16]}$

The two remaining students did work in chemistry in the US, but neither had any significant impact on the development of the field of inorganic chemistry. Victor L. King (1886-1958) was responsible for what is arguably the most significant of Werner's publications (although he was given only the 'with' credit described above ${ }^{[17]}$ ), the first reported successful resolution of an optically active coordination complex. He spent the rest of a long and successful career in industrial chemistry, primarily with Calco (which subsequently became part of American Cyanamid), specializing in dyestuffs and related technologies; there is no indication that he ever worked in coordination chemistry again. ${ }^{[18]}$

Kauffman lists no Werner paper with the participation of Helen Somersby

\title{
Beitrag zur Konstitution anorganischer Verbindungen.
}

Von

ALFRED WERNER.

XIX. Mitteilung.

\author{
Über Platinoxalatoverbindungen. \\ Experimentell bearbeitet von E. GRBBE.
}

Durch die Litteraturangabe, dafs die Salze der Platosoxalsäuren in zwei isomeren Formen auftreten, wurde ich gelegentlich der Entwickelung der Theorie der geometrisch-isomeren Verbindungen des zweiwertigen Platins $\mathrm{Pt}_{\mathrm{X}_{2}}^{\mathrm{A}_{2}}$, zur Ansicht gedrängt, dafs auch diese isomeren Salze durch sterische Formeln zu erklären seien. Es hat sich in der Folgezeit herausgestellt, dafs diese Erklärung auf die betreffenden Verbindungen darum keine Anwendung finden kann, weil dieselben überhaupt nicht isomer sind, sondern sich von verschiedenen Wertigkeitsstufen des Platins ableiten.

Wie ich schon früher gezeigt habe, hat man bei den Oxalsäureverbindungen des Platins drei verschiedene Verbindungsklassen zu unterscheiden: 1. die wirklichen platosoxalsauren Salze, 2. die aus ersteren durch Anlagerung von Chlor, unter Übergang des zweiwertigen Platins in vierwertiges, entstehenden dichloroplatinoxalsauren Salze, ${ }_{\mathrm{Pt}}-\mathrm{CO}_{2} \mathrm{CO}_{2} \mathrm{~K}$, und 3. die Mischsubstanzen, die sich durch Ver$-\mathrm{CO}_{2} \mathrm{CO}_{2} \mathrm{~K}$
-

einigung von Verbindungen der Klasse 1 mit solchen der Klasse 3 bilden und deshalb z. B. auch bei der Einwirkung von Halogen auf platosoxalsaure Salze als Zwischenprodukte auftreten.

Ich habe in der Erwartung, dais bei den platosoxalsauren Salzen vielleicht doch auch Stereoisomerie auftreten könnte, und um etwas

French (1884-1975), but does refer to her thesis, which had the intriguing title 'The Absorption Spectra of Certain Chromium Salts.' ${ }^{[19]}$ She subsequently returned to her alma mater, Wellesley College, where she had been a faculty assistant before doing her $\mathrm{PhD}$, and remained as a professor of inorganic chemistry until 1950, publishing around a dozen papers - most of them in coordination chemistry - during her career. However, there is no indication that she trained any students who continued in the field - indeed, one of her students recalls French discouraging her from going on to post-graduate work because "you'll just get married"![20]

Werner's two postdoctoral/visiting associates (if there were only two) are easier to trace; unlike his students, Werner was willing to grant them co-authorial credit (although perhaps not always reliably: see Fig. 4![21]). Charles Holmes Herty (18671938), a faculty member at the University of Georgia, spent the year 1899-1900 on sabbatical in Europe working with several distinguished chemists, including Walter Nernst, in addition to Werner. Herty published a paper with Werner on inorganic compounds, ${ }^{[22]}$ but although he had a very successful career in both academia and industry - including a term as president of the American Chemical Society - after returning to the US, he, like King, abandoned that field completely. ${ }^{[23]}$ In contrast,
Thomas P. McCutcheon, who published a paper on asymmetric cobalt complexes with Werner in 1912, ${ }^{211]}$ joined the chemistry department of the University of Pennsylvania as an inorganic chemist, and published a dozen or so inorganic papers, many on the chemistry of the heteropoly acids. Of those students who appear as coauthors on those papers, only one - L. C. W. Baker - appears to have continued in the field, continuing to work on HPAs at Georgetown University.

In all, then, there is little evidence of any major influence on the field through Werner's line of academic descendants. Most left no trace in chemistry at all; two were significant figures in American chemistry, but not in inorganic; and two, while continuing to contribute to the field, did not establish a really major program of their own.

\section{Werner's Influence on the American Inorganic Renaissance}

Nyholm claimed that advances in physical and theoretical methodology were primarily responsible for the (world-wide) renaissance of inorganic chemistry. ${ }^{[5]} \mathrm{My}$ view is that the main drivers were conceptual, not pragmatic, and were internal, not external, to the field; specifically, that burgeoning interest in mechanistic investi- 


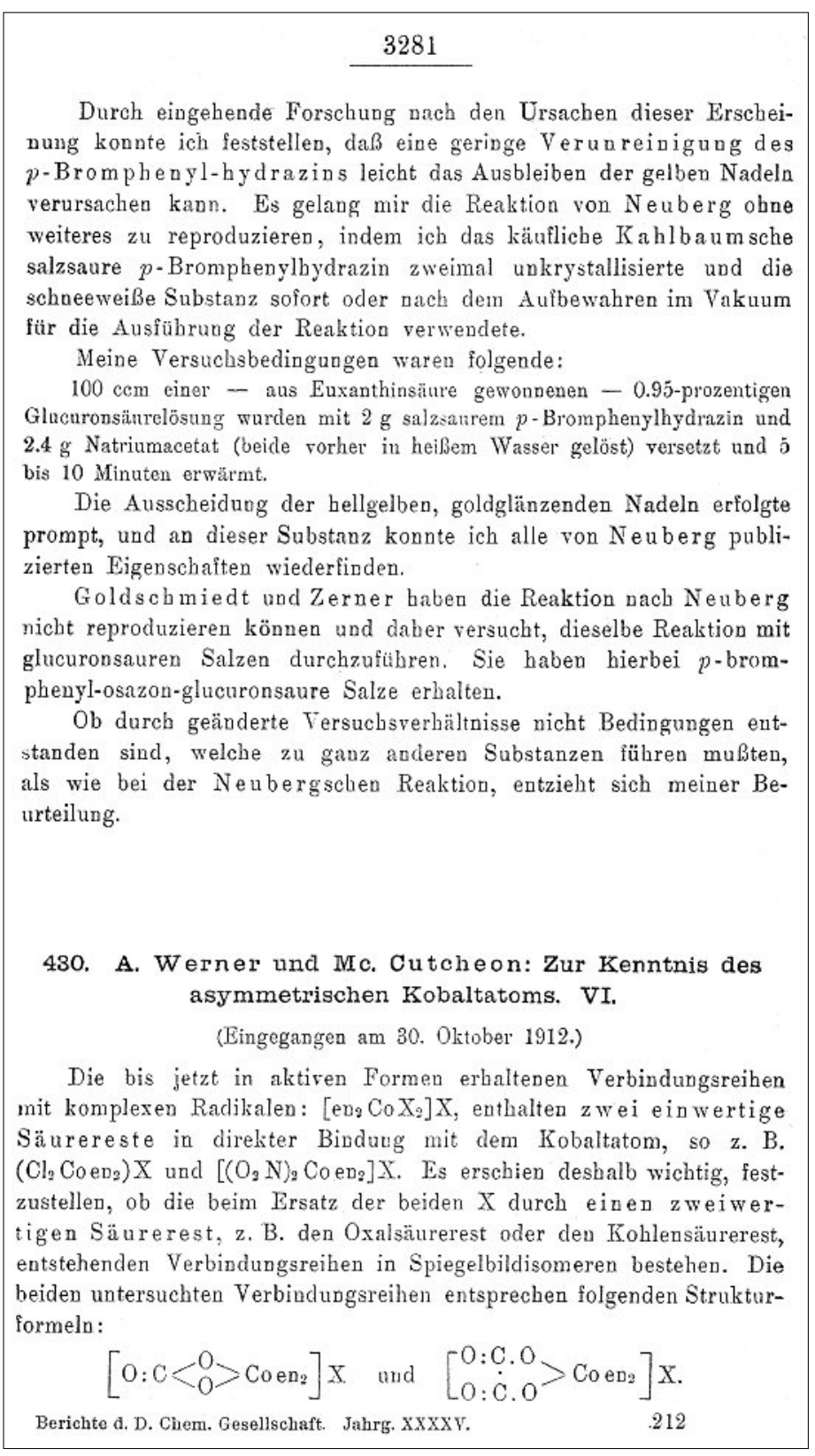

gations along with the upsurge in organotransition metal chemistry effectively remade inorganic chemistry as a much more explanatory discipline, thus attracting an aura of intellectual respectability that had been previously lacking. ${ }^{[4]}$ Whichever we believe was the more important factor, can we trace any of these new developments to Werner's heritage?

Theoretical approaches to chemical understanding (in the quantum mechanical sense that Nyholm is referring to) did not exist in Werner's time, but physical/instrumental methods of characterization (aside from polarimetry, which already had a long history, and of course played a major role in Werner's research) were then coming into use. However, Kauffman suggests that Werner was not all that enthusiastic about these developments:

"[A]nother of the trends which is par-
Fig. 4. First page of ref. [21]: postdoctoral associate T. P. McCutcheon did receive authorial credit, but in distorted form.
Werner involve himself with X-ray crystallography, which was just beginning to take on the central role it has since occupied in inorganic chemistry:

“In view of Werner's penchant for thinking in three-dimensional geometric terms...it is surprising that he did not apply his coordination theory directly to the domain of crystallography. Yet he did not.... it remained for Paul Pfeiffer... and others to point out that crystal structures were in beautiful agreement with his coordination theory, as revealed by the then new experimental technique of $X$-ray diffraction."[24]

If physical methodology is not the link, what is? I identify it as the crucial introduction of mechanistic thinking to American inorganic chemistry, which can arguably be traced back to an individual who was directly and strongly influenced by Werner's work. John Bailar, like Werner, started his career as an organic chemist, obtaining his $\mathrm{PhD}$ at the University of Michigan with Moses Gomberg. He was hired in 1928 by the University of Illinois at Urbana/Champaign, primarily to teach general chemistry, and became interested in some questions students raised about inorganic topics, such as isomerism; also he perceived that the great strength of the organic group at Illinois meant he would have little chance of staying on as an organic chemist. [25] In searching for a research program, he took his inspiration directly from Werner's work, as Fred Basolo - one of Bailar's most notable $\mathrm{PhD}$ students - later recounted:

"John believed that he should do research on an inorganic problem. After some time in the library, he found that papers by Alfred Werner were of interest to him. These Werner metal complexes, with geometric and stereo isomers, could be studied in a manner similar to that of organic compounds. In fact, John did such a good job with his research on these systems that he is viewed by chemists as the 'Father of Coordination Chemistry in the US.' "[26]

That attribution of paternity was supported by an external observer, the British inorganic chemist Joseph Chatt:

"On my first visits to the United States, I noted that there were only two types of coordination chemists there, those who had been John Bailar's students and those who had not, and the former appeared greatly to outnumber the latter." [11]

The importance of mechanistic questions in reactions of octahedral complexes had been anticipated by Werner as early as $1912,[27,28]$ and Bailar's first venture into 
the field followed Werner's mechanistic legacy:

"In 1893 Paul Walden [1863-1957] discovered the very interesting inversion reaction which bears his name. It was an extremely important discovery, for it called attention to the chemists of that day that reactions have mechanisms. It occurred to me that if we repeated Werner's experiment....we might also get an inversion.... if we could get an inversion with an octahedral model rather than a tetrahedral one, we might be able to rule out some of the theories which had been advanced for the inversion in reactions of the tetrahedral organic molecules."[29]

In that experiment Bailar and his student Robert Auten found that the reactions of $\mathrm{L}$-cis- $\left[\mathrm{Coen}_{2} \mathrm{Cl}_{2}\right]^{+}$(en = ethylenediamine) with potassium carbonate and silver carbonate gave the $\mathrm{D}$ - and $\mathrm{L}$-isomers of $\left[\mathrm{Coen}_{2}\left(\mathrm{CO}_{3}\right)\right]^{+}$respectively, meaning that one of them had proceeded with inversion at the Co center, although their data did not conclusively determine which one that was; nor did they offer any conclusions or even speculations about mechanism. [30]

Subsequently Bailar and others, most notably Basolo, found that both the reactivity and the mechanistic interpretation were rather more complex than originally suspected. ${ }^{[31]}$ But this work by Bailar and his successors - many of whom were his direct academic descendants - sparked the mechanistic turn that played a crucial role in raising the image of inorganic chemistry to a par with that of organic and physical chemistry. One representation of that impact can be seen from the extent to which those descendants dominated the field in American academia: in 1983, fully a quarter of the inorganic faculty received their $\mathrm{PhD}$ and/or postdoctoral training from that single ancestral line that traces back to Bailar (Fig. 5) - and through him, spiritually, to Werner. In that sense at least, even though Werner's own students and postdocs were relatively minor players, the importance of Werner's legacy to the inorganic boom that began in the mid-20th century was enormous.

Received: February 17, 2014

[1] F. J. Moore, 'A History of Chemistry' (revised by W. T. Hall), McGraw Hill, New York, 1918/1931, p. 237.

[2] T. H. Levere, 'Transforming Matter: A History of Chemistry from Alchemy to the Buckyball', Johns Hopkins Press, Baltimore, 2001, p. 148.

[3] E. von Meyer, 'A History of Chemistry from Earliest Times to the Present Day' (3rd English edition, translated by G. McGowan), Macmillan \& Co., London, 1906, p. 417.

[4] J. A. Labinger, 'Up from Generality: How Inorganic Chemistry Finally Became a Respectable Field', Springer, Heidelberg, 2013.

[5] R. S. Nyholm, J. Chem. Educ. 1957, 34, 166.

[6] M. J. Nye, 'Before Big Science: The Pursuit of Modern Chemistry and Physics, 1800-1940', Twayne Publishers, New York, 1996, p. xv.

[7] C. A. Russell, 'The Structure of Chemistry', Unit 3. Open University Press, Milton Keynes, 1976.

[8] G. B. Kauffman, 'Alfred Werner, Founder of Coordination Chemistry', Springer, Berlin, 1966.

[9] A. Werner, Z. Anorg. Chem. 1893, 3, 267.

[10] E. C. Constable, C. E. Housecroft, Chem. Soc. Rev. 2013, 42, 1429.

[11] J. Chatt, in 'Coordination Chemistry: A Century of Progress', Ed. G. B. Kauffmann, American Chemical Society, Washington, 1994, p. xiv.

[12] G. B. Kauffmann, in 'Coordination Chemistry: A Century of Progress', Ed. G. B. Kauffmann, American Chemical Society, Washington, 1994, p. ix.
[13] I. Bernal, G. B. Kauffman, J. Chem. Educ. 1989, 66, 293.

[14] A. Werner, Z. Anorg. Chem. 1899, 21, 377.

[15] A. Werner, Ber. 1906, 39, 185.

[16] L. Beyer, E. Hoyer, Z. Anorg. Allg. Chem. 2011, $637,1880$.

[17] A. Werner, Ber. 1911, 44, 1887.

[18] G. B. Kauffman, 'Classics in Coordination Chemistry, Part 1: The Selected Papers of Alfred Werner', Dover Publications, New York, 1968, pp. 157-8.

[19] G. B. Kauffman, Coord. Chem. Rev. 1975, 15,

[20] N. H. Kolodny, J. A. Darlington, H. C. Mann, E. R. Webster, '125 Years in the Chemistry Department at Wellesley College', downloaded from the website http://www.wellesley.edu/ chemistry/departmenthistory.

[21] A. Werner, Mc. Cutcheon (sic), Ber. 1912, 45, 3281.

[22] A. Werner, C. Herty, Z. Physik. Chem. 1901, 38, 331.

[23] From Wikipedia, http://en.wikipedia.org/wiki/ Charles_Herty.

[24] G. B. Kauffman, 'Classics in Coordination Chemistry, Part 3: Twentieth Century Papers', Dover Publications, New York, 1978, pp. 75-7.

[25] J. C. Bailar, interview by Theodore L. Brown at University of Illinois, Urbana, Urbana, Illinois, 28 May \& 17 June 1987, Philadelphia: Chemical Heritage Foundation, Oral History Transcript \# 0073, 1987.

[26] F. Basolo, 'From Coello to inorganic chemistry: a lifetime of reactions', Kluwer, New York, 2002, p. 15.

[27] A. Werner, Annalen 1912, 386, 1.

[28] A. Werner, Ber. 1912, 45, 3061.

[29] G. B. Kauffman, G. S. Girolami, D. H. Busch, Coord. Chem. Rev. 1993, 128, 1.

[30] J. C. Bailar, R. W. Auten, J. Am. Chem. Soc. 1934, 56, 774.

[31] F. Basolo, in 'Werner Centennial' (ACS Advances in Chemistry Series No. 62) 1967, pp. 408-29.

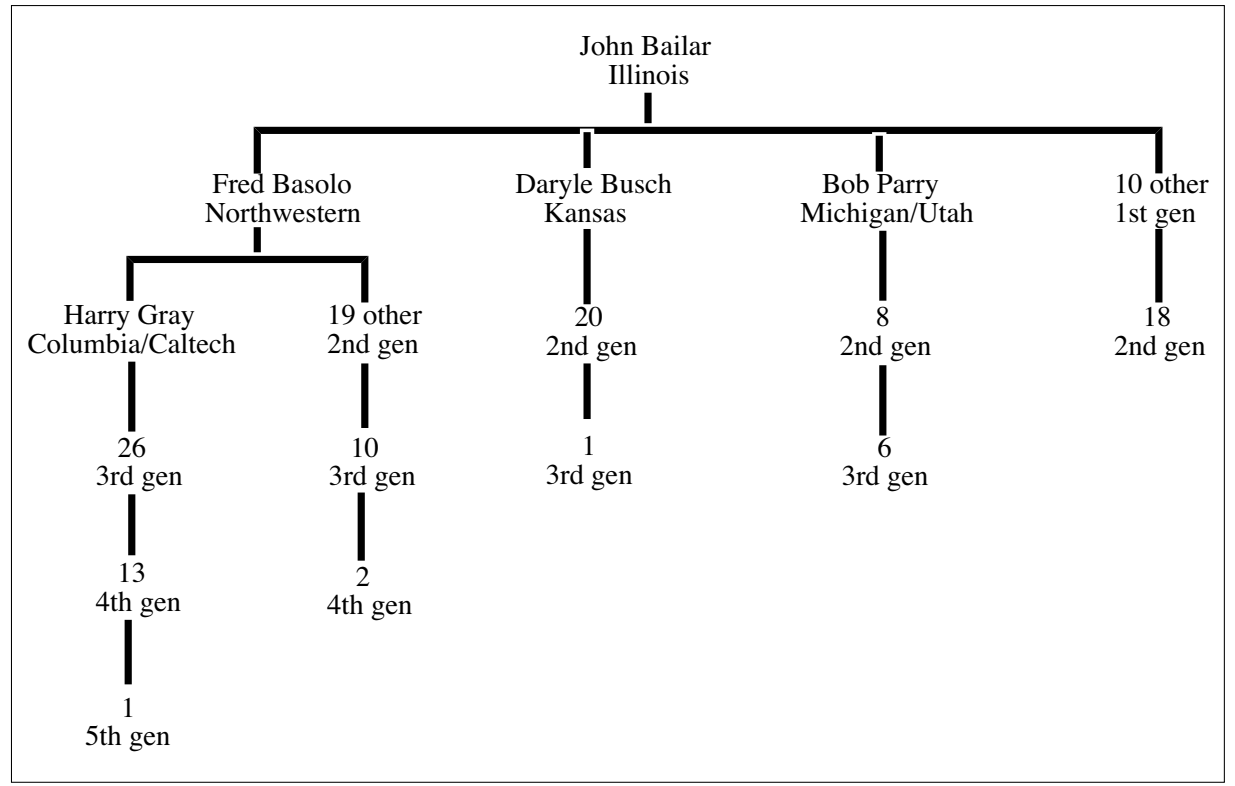

Fig. 5. Family tree of inorganic faculty in US PhD-granting departments in 1983 whose academic descent traces back to Bailar's group. 